\title{
Sudden Phytophthora Dieback of Wild Cherry Trees in Northwest Hungary
}

\author{
Judit SÁRÁNDI-KOVÁCs ${ }^{\mathrm{a}^{*}}$ - László NAGY ${ }^{\mathrm{b}}$ - Ferenc LAKATOS ${ }^{\mathrm{a}}$ - György SIPOS ${ }^{\mathrm{a}, \mathrm{c}}$ \\ ${ }^{a}$ Institute of Silviculture and Forest Protection, Faculty of Forestry, University of West-Hungary, Sopron, Hungary \\ ${ }^{\mathrm{b}}$ Szombathely Forestry Corporation, Sárvár Forestry Directorate, Sárvár, Hungary \\ ${ }^{c}$ WSL, Swiss Federal Research Institute, Birmensdorf, Switzerland
}

\begin{abstract}
During a regular survey of declining forests in 2011, sudden dieback symptoms were observed on scattered wild cherry trees (Prunus avium) in a mixed deciduous forest stand, located in the flood plain area of the Rába River, in northwest Hungary. In this study, we correlated both soil conditions and presence of Phytophthora spp. to dieback of cherry trees. Two Phytophthora species, $P$. polonica and $P$. plurivora, were isolated from the rhizosphere soil of the dying trees. By contrast, only $P$. polonica was recovered from the necrotic tissues of symptomatic roots. Stem and root inoculation tests on cherry seedlings showed pathogenicity of both species, although $P$. polonica proved to be more virulent. This is the first report of natural infections of $P$. polonica.
\end{abstract}

soilborne pathogens / forest protection / Phytophthora polonica / Phytophthora plurivora

Kivonat - Madárcseresznye fák fitoftórás pusztulása Északnyugat-Magyarországon. Egy 2011-ben, pusztuló erd állományokban végzett egészségi állapot-felmérés során egy elegyes erd állományban a madárcseresznye fák pusztulására figyeltek fel a szerz k. Az erd állomány a Rába folyó egy holtága mentén terül el. Egy két éves esettanulmány során, talajvizsgálatot és a talaj és a talált Phytophthora fajok hatását vizsgáló patogenitásteszteket végeztünk. Eredményeinket statisztikailag értékeltuik. Míg az erd állomány talajából Phytophthora plurivorát és Phytophthora polonicát tenyésztettünk ki, a pusztuló fák tuineteket mutató gyökereib 1 csak $P$. polonicát sikerült izolálni. Madárcseresznye-csemetéken elvégzett törzssebzési és gyökérfert zési kísérletek egyaránt kimutatták mindkét izolált faj patogenitását. agresszivitását statisztikai elemzések bizonyítják. Ez az els olyan alkalom, amikor természetes körülmények között a $P$. polonica kórokozónak bizonyult.

talajlakó kórokozó / erd védelem / Phytophthora polonica / Phytophthora plurivora

\section{INTRODUCTION}

Wild cherry (Prunus avium L.) is present in Hungarian mixed deciduous forests as scattered trees. Besides fungal and bacterial pathogens, several Phytophthora species are known to cause dieback of cherry trees under natural or experimental conditions (Santini et al. 2006, Kurbetli 2014, Vettraino et al. 2008). Among Phytophthora species, P. alni Brasier \& S. A. Kirk, P. cactorum (Lebert \& Cohn) J. Schröt., P. cambivora (Petri) Buisman, P. cinnamomi Rands, P. citricola Sawada, P. citrophthora (R. E. Sm. \& E. H. Sm.) Leonian, P. cryptogea

\footnotetext{
* Corresponding author: sarandi-kovacs.judit@emk.nyme.hu; H-9400 SOPRON, Bajcsy-Zs. u. 4. Hungary
} 
Pethybr. \& Laff., P. drechsleri Tucker, P. megasperma Drechsler, P. nicotianae Breda de Hahn and $P$. syringae (Kleb.) Kleb. are known to cause dieback of cherry trees under natural or experimental conditions (Mircetich - Matheron 1976, Thomidis - Sotiropoulos 2003, Santini et al. 2006, Thomidis et al. 2008, Vettraino et al. 2008). In this paper we describe the sudden death of wild cherry trees in northwest Hungary and evaluate the role of the combined impact of soil texture and soilborne Phytophthora spp. in the etiology of the disease.

\section{MATERIALS AND METHODS}

\subsection{Isolation}

In spring 2012 sudden dieback of twelve-year-old wild cherry trees was surveyed in a 1.84 ha mixed deciduous forest stand (pedunculate oak: $60 \%$, common ash: $25 \%$, wild cherry: 5\%, eastern black walnut: 5\%, other broadleaved tree species: 5\%) partly surrounded by a backwater of the Rába River, near Sárvár (150 m above sea level) in northwest Hungary. Six symptomatic trees were randomly selected and necrotic root and rhizosphere soil samples were collected in a total amount of $500 \mathrm{~g} / \mathrm{sample}$. Both sample types were processed as previously described (Szabó et al. 2013). To recover Phytophthora isolates from the soil samples, cherry laurel (Prunus laurocerasus L.) and Rhododendron sp. leaves were used as baits. The infected leaf segments were placed onto selective PARPNH media (Jung et al. 2000). Morphological characterization was carried out as described by Szabó et al. (2013). All of the collected isolates were examined. For molecular identification, pure mycelial cultures were used for direct PCR with the PHIRE Plant Direct PCR Kit (Thermo Scientific) according to the manufacturer's user's guide. The ITS1-5.8S-ITS2 regions of the rDNA of selected isolates were amplified using the ITS6 and ITS4 primer pair (Cooke - Duncan 1997) in an Eppendorf Mastercycler Personal PCR machine. PCR conditions were as follows: 5 min initial denaturation at $98^{\circ} \mathrm{C}, 5 \mathrm{~s}$ denaturation at $98^{\circ} \mathrm{C}, 5 \mathrm{~s}$ annealing at $55^{\circ} \mathrm{C}, 20 \mathrm{~s}$ extension at $72{ }^{\circ} \mathrm{C}$ ( $1 \mathrm{~min}$ for the final cycle) with 39 cycles in total. The amplified DNA fragments were sequenced in both directions in the Eurofin Laboratory (Ebersberg, Germany). All of the six collected isolates were sequenced and their sequence homologues were identified using Blast searches against the NCBI GenBank database (http://blast.ncbi.nlm.nih.gov/Blast.cgi). Accession numbers: KT693123; KT693124; KT693125; KT693126; KT693127; KT693128).

\subsection{Pathogenicity tests}

Pathogenicity tests were performed using two different soil conditions to compare the effect of the local sandy alluvial soil versus the control soil type typical of the forests of the region. Both soil types proved to be free of Phytophthora species prior to infestation according to the result of leaf baiting controls. Soil analyses were performed in the WSL soil laboratory (Swiss Federal Research Institute, Birmensdorf, Switzerland). The pathogenicity of one P. plurivora (Jung - Burgess 2009) and one P. polonica (Belbahri - Moralejo - Lefort 2011) isolate (both 14 days old, grown on $39 \mathrm{~g} / \mathrm{l} \mathrm{PDA}$ at $20^{\circ} \mathrm{C}$ in the dark) was assessed in both soil types (sandy alluvial and control soils). Stem inoculation and root infection tests were carried out on twoyear-old, container-grown wild cherry seedlings, using 10 replicates per Phytophthora species and 10 replicates as control (not infected). For root infection, four equal aliquots of mycelial culture were put into the planting medium in four directions around the stem of the seedlings (altogether two cultures/seedling). Stems were wound inoculated by inserting an infested PDA plug (5-mm in diameter) under the bark using a sterile scalpel. Control seedlings were inoculated with sterile PDA. Wounds were sealed with Parafilm (Pechiney, Chicago, IL). Seedlings were maintained under outdoor natural conditions and were watered when 
necessary. Lesion sizes were measured and the health condition of the shoots and roots was evaluated based on a five-point scale 13 weeks after inoculation (see Table 1). Necrotic tissues from the stem and roots of infected seedlings, and soil samples from the container of infected seedlings were collected for the re-isolation of Phytophthora species in order to fulfill Koch's postulates.

\subsection{Statistical analyses}

Statistical analyses were performed with STATISTICA 12 software (StatSoft, Inc. [2014]). Kruskal-Wallis and Mann-Whitney U tests were used for the comparison of the treatment groups. The effects of the two contributing factors (pathogen versus soil type) were evaluated both separately and together. Pearson Chi-square tests were performed to evaluate whether there is a significant correlation between treatments applied and the parameters of the root system. Boxplots were created and edited using SPSS (IBM, v. 22).

Table 1: The five-point scale used for the evaluation of pathogenicity tests

\begin{tabular}{cll}
\hline Stage & Crown symptom & Root symptom \\
\hline 1 & Asymptomatic sapling & $\begin{array}{l}\text { Healthy root system with plentiful healthy } \\
\text { fine roots } \\
\text { Dead root tips and fine roots occurring } \\
\text { locally (less than } 30 \%) \\
30 \%-50 \% \text { of the root system is already } \\
\text { dead }\end{array}$ \\
$\begin{array}{l}\text { Smaller leaves with yellowish } \\
\text { discolouration }\end{array}$ & $\begin{array}{l}\text { More than } 50 \% \text { of the root system is } \\
\text { already dead }\end{array}$ \\
4 & More than $50 \%$ of the crown is dead & $\begin{array}{l}\text { Completely dead sapling } \\
5\end{array}$ \\
\hline
\end{tabular}

\section{RESULTS}

\subsection{Isolation and identification}

Sudden dieback of young wild cherry trees was clearly observed in a forest stand at the inundation area of the Rába River at the time of budburst in spring 2012. Approximately $70 \%$ of the wild cherry trees showed severe wilting symptoms or were already dead. Bark cracking and stripping, gummosis and wood discoloration under necrotic bark on the lower stems and also necroses on the main roots were observed. Six Phytophthora isolates were obtained from five from of the six soil samples using leaf baiting and a single isolate from the necrotic tissues. Based on the comparison of morphological traits and homology $(99-100 \%)$ to other ITS sequences, four P. polonica (three from the soil and one from necrotic tissues) and two P. plurivora isolates (both from the soil) were identified. The isolates of the two species could be easily distinguished based on the daily growth rate, the shape and amount of sporangia produced and the presence or absence of hyphal swellings. While the two $P$. plurivora isolates had a daily growth rate $6.50-6.83 \mathrm{~mm}$, $P$. polonica colonies grew more slowly $(4.50-4.67 \mathrm{~mm} /$ day). The colonies of $P$. plurivora isolates formed readily and abundantly sporangia with variable shapes but hyphal swellings were absent. In contrast, $P$. polonica isolates produced abundantly single or catenulate hyphal swellings either with globose or irregular shapes and only two isolates formed a few, ovoid, non-papillate sporangia. 
The analysis of the soil types illustrated that the base saturation values were nearly identical and only soil textures were different (Table 2).

Table 2: Soil types used for the pathogenicity tests

\begin{tabular}{|c|c|c|c|}
\hline & & Sárvár & Control soil \\
\hline Texture & (\% sand, silt, clay) & $61,24,15$ & $12,54,34$ \\
\hline $\mathrm{pH}$ & $\left(0.02 \mathrm{M} \mathrm{CaCl}_{2}\right)$ & 5.06 & 7.35 \\
\hline $\mathrm{Ca}_{\mathrm{exch}}$ & $\left(\mathrm{mg} \mathrm{kg}^{-1}\right)$ & 3819.39 & 6983.97 \\
\hline $\mathrm{Mg}_{\text {exch }}$ & $\left(\mathrm{mg} \mathrm{kg}^{-1}\right)$ & 604.76 & 700.45 \\
\hline $\mathrm{K}_{\text {exch }}$ & $\left(\mathrm{mg} \mathrm{kg}^{-1}\right)$ & 269.37 & 431.95 \\
\hline $\mathrm{Na}_{\text {exch }}$ & $\left(\mathrm{mg} \mathrm{kg}^{-1}\right)$ & $<5.20$ & 14.83 \\
\hline $\mathrm{Mn}_{\text {exch }}$ & $\left(\mathrm{mg} \mathrm{kg}^{-1}\right)$ & 67.81 & 6.95 \\
\hline $\mathrm{Fe}_{\text {exch }}$ & $\left(\mathrm{mg} \mathrm{kg}^{-1}\right)$ & 2.75 & $<1.60$ \\
\hline $\mathrm{Zn}_{\mathrm{exch}}$ & $\left(\mathrm{mg} \mathrm{kg}^{-1}\right)$ & 1.27 & $<1.20$ \\
\hline $\mathrm{Al}_{\text {exch }}$ & $\left(\mathrm{mg} \mathrm{kg}^{-1}\right)$ & 3.52 & $<2.00$ \\
\hline CEC & $\left(\mathrm{mmol}_{\mathrm{c}} / \mathrm{kg}\right)$ & 125.13 & 209.03 \\
\hline Base sat & $(\%)$ & 98.80 & 99.94 \\
\hline
\end{tabular}

\subsection{Pathogenicity tests}

In the case of the uninfected seedlings, the root system remained healthy and rich in fine roots. In contrast, altogether six $P$. polonica-, and four $P$. plurivora-infested seedlings died during the thirteen weeks of the root infection experiment. Thinned root system, dead fine roots and root tips, and extremely short main roots were observed (Figure 1). Significant differences in the health conditions of roots $(\mathrm{p}=0.000)$ and in the root widths $(\mathrm{p}=0.000)$ were identified according to the results of the Kruskal-Wallis tests. For the roots' health conditions (Figure $2 A)$, both the effect of soil type $(\mathrm{p}=0.015)$ and the pathogen $(\mathrm{p}=0.000)$ were significant according to the results of the Kruskal-Wallis tests. There was a significant correlation between the applied treatment and the health condition of the root system $(\mathrm{p}=0.00000)$ according to the Pearson Chi-square test. Altough, there wasn't any significant correlation between the applied treatment and the root width based on the Pearson Chi-square test. $P$. polonica seemed to be slightly more aggressive than $P$. plurivora. Both Phytophthora species were re-isolated from symptomatic roots and from the infected growth media.

In the stem inoculation experiment, sunken and dark necrotic lesions developed at the inoculation points of infected seedlings while only callus formation was observed on the control stems. Significant differences in the health conditions of shoots $(p=0.002)$ and necrotic areas $(\mathrm{p}=0.001)$ were found between the treatment groups according to the results of the Kruskal-Wallis tests. For shoot health conditions (Figure 2B), only the effect of soil type was significant $(\mathrm{p}=0.000)$ and the soil type did not have a significant impact on the size of the necrosis on the stems (Figure 2C). There was no significant difference in the aggressivity of the two species. Both Phytophthora species were reisolated from the border of the lesions. 


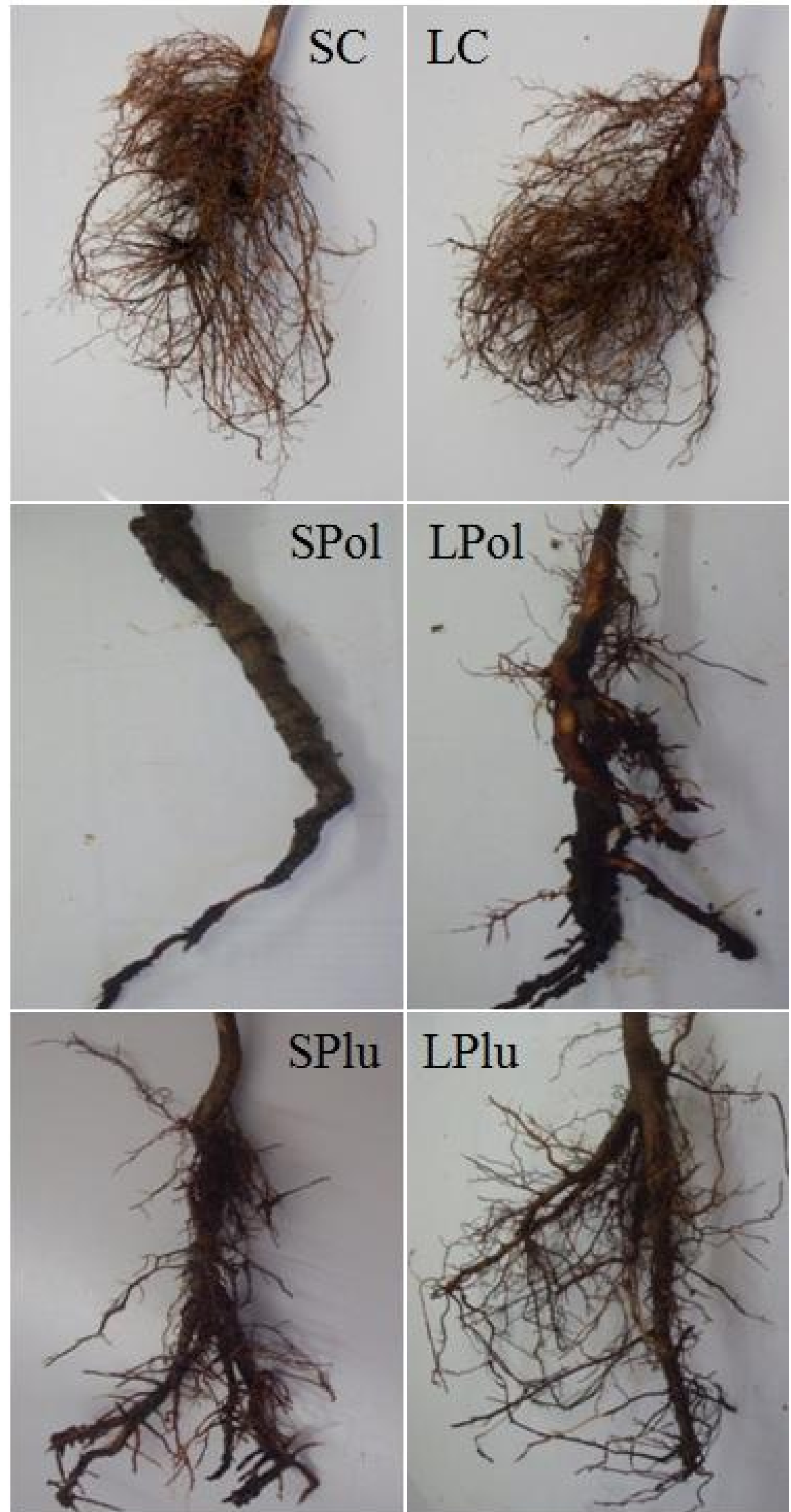

Figure 1. Root development in soil infection test (Abbreviations: L: control soil type, S: local alluvial soil type, Pol: P. polonica, Plu: P. plurivora, C: non-infected control) 


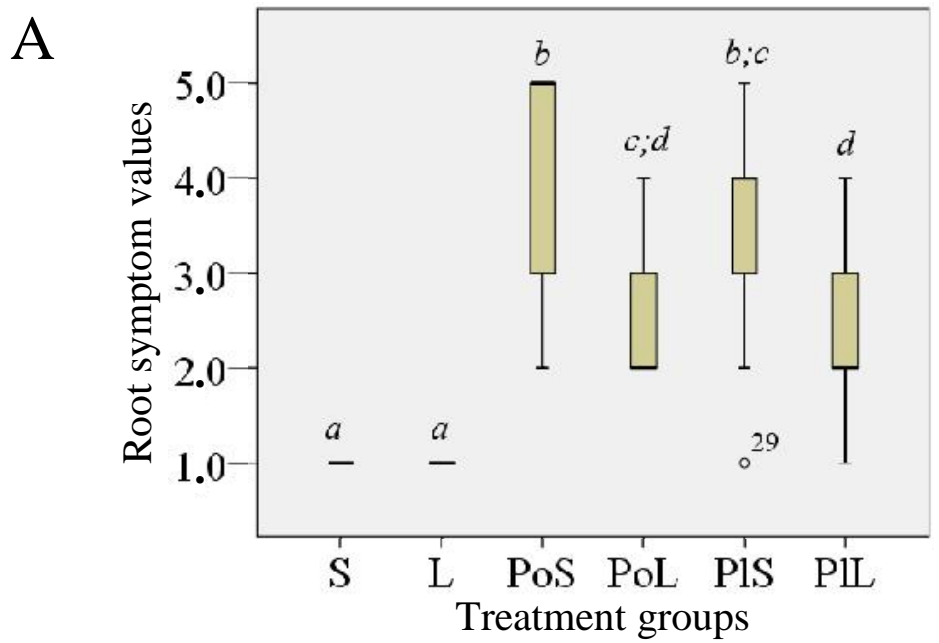

B
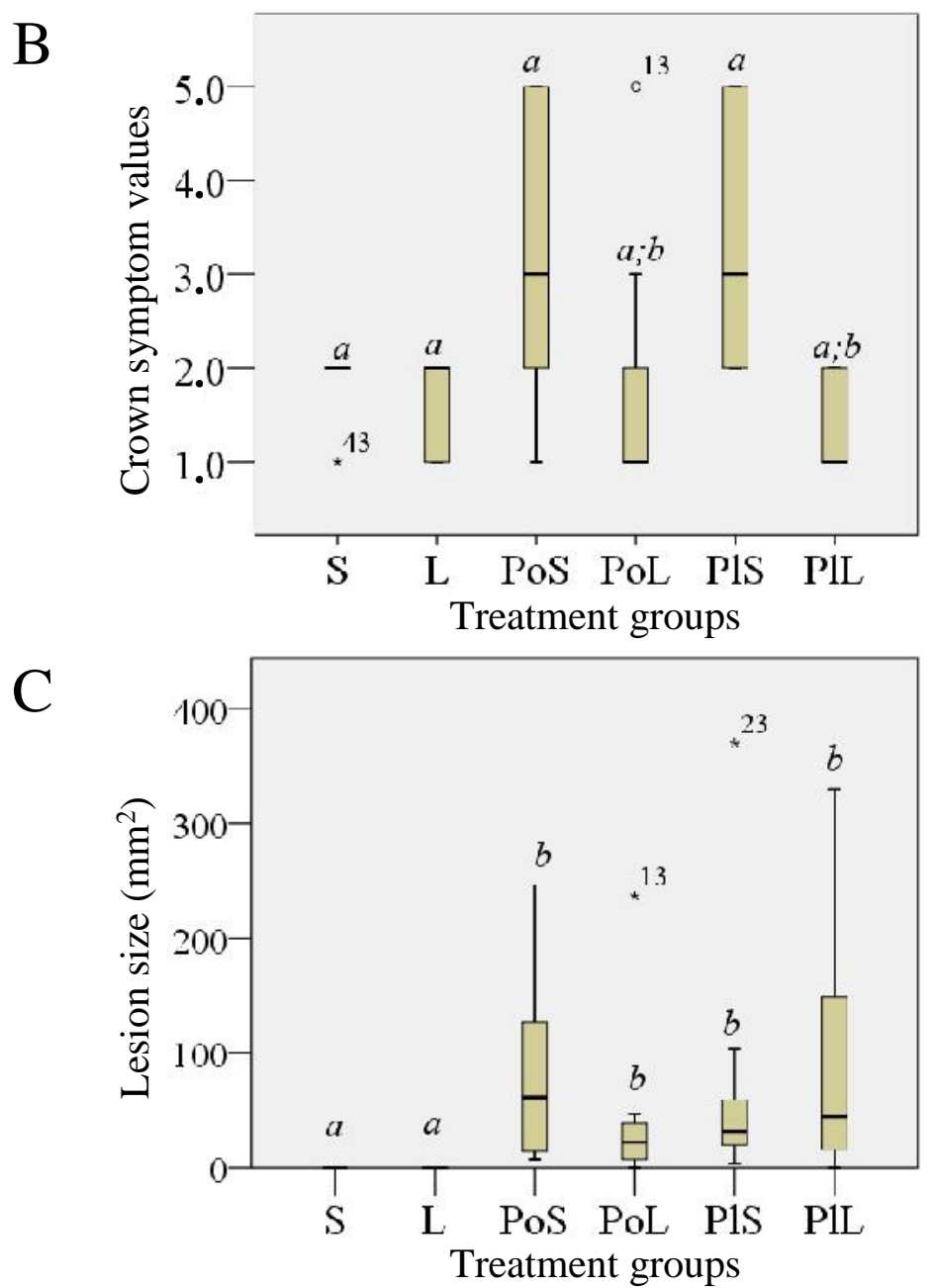

Figure 2.

A: Root system health conditions in the different treatment groups (mean values; different labels mean significantly different groups based on the Mann-Whitney U test).

B: Health conditions based on crown symptoms in the different treatment groups (mean values; different labels mean significantly different groups based on the Mann-Whitney U test).

$C$ : Lesion sizes in the different treatment groups (mean values; different labels mean significantly different groups based on the Mann-Whitney U test). 


\section{DISCUSSION}

The main goal of our study was to determine the causal agents of the selective wild cherry mortality in a mixed deciduous forest stand growing in a flooded riverside area. Initially, the sandy alluvial soil and the impact of the fluctuating water levels were suspected as they represent poor growth conditions for cherry trees. However, various bark cracking and necrosis symptoms in the trees that were still alive indicated a possible Phytophthora infection. At the same time, we did not observe any visible symptoms of a potential fungal or bacterial attack, neither in the dead, nor in the dying trees. The recovery of $P$. polonica, from both the necrotic tissues and the rhizosphere soil of the dying trees, suggested a primary role of this Phytophthora species in the observed dieback. P. plurivora, regarded as a pathogenic species (Oßwald et al. 2014), was also isolated from the soil and was considered as a potential contributing factor to the rapid decline of the trees.

Stem and root infection tests demonstrated the pathogenicity of both Phytophthora species, with $P$. polonica showing slightly more virulence against wild cherry seedlings. The significant differences in the root infection between the two different planting media used suggest that the poor site conditions may have led to weakened immunity in the wild cherry trees. The unusually high precipitation in the region, which occurred in August $2011(112 \mathrm{~mm})$, combined with the loose sandy soil texture, may have caused ideal environmental circumstances that exposed the vulnerable cherry trees to a rapid Phytophthora invasion.

Although all cherry trees were planted ones, suggesting that the pathogen may have emerged and been introduced to the forest site from a nursery, the seedlings were indeed grown from local seed resources in a nearby nursery. Therefore, the origin of the pathogen remains still unclear and a recent colonization of the forest site cannot be ruled out.

While $P$. plurivora has previously been associated with the decline of various forest stands in Hungary (Szabó et al. 2013), this is the first report of $P$. polonica being directly involved in rapid tree mortality. Since 2012, no similar decline of wild cherry trees has been reported in Hungary. Nevertheless, our results provide a warning of a potential threat to Prunus species and highlight the importance of considering site conditions when planning plantations or reforestations.

Acknowledgements: The authors would like to thank their Hungarian colleagues and family members who helped with the field work and pathogenicity tests, and to Professor Ilona Szabó (University of West-Hungary, Sopron, Hungary), for her helpful comments. We are also grateful to Roger Köchli, Dr. Stephan Zimmermann, Roland Engesser (WSL Birmensdorf, Switzerland) for the soil analysis and advice, and to Curtis Gautschi (WSL Bellinzona, Switzerland) for his helpful comments and English correction. This work was supported by the "AGRÁRKLÍMA.2 VKSZ_12-1-2013-0034" grant in Hungary.

\section{REFERENCES}

Belbahri, L. - Moralejo, E. - CAlmin, G. - Oszako, T. - García, J.A. - Descals, E. LEFORT, F. (2006): Phytophthora polonica, a new species isolated from declining Alnus glutinosa stands in Poland. FEMS Microbiological Letters 261: 165-174.

COOKE, D.E.L. - DUNCAN, J.M. (1997): Phylogenetic analysis of Phytophthora species based on ITS1 and ITS2 sequences of the ribosomal RNA gene repeat. Mycological Research 101 (6): 667-677.

JUNG, T. - BLASCHKE, H. - OSSWALD, W. (2000): Involvement of soilborne Phytophthora species in Central European oak decline and the effect of site factors on the disease. Plant Pathology 49: 706-718. 
JUNG, T. - BURGESS, T.I. (2009): Re-evaluation of Phytophthora citricola isolates from multiple woody hosts in Europe and North America reveals a new species, Phytophthora plurivora sp. nov. Persoonia 22: 95-110.

KURBETLI, I. (2014): Involvement of Phytophthora cryptogea in sweet cherry decline in Turkey. Phytoparasitica 42 (5): 627-630.

Mircetich, S.M. - MATHERON, M. E. (1976): Phytophthora root and crown rot of cherry trees. Phytopathology. 66: 549-558.

ObWald, W. - Fleischmann, F. - Rigling, D. - Coelho, A. C. - Cravador, A. - Diez, J. Dalio, R.J. - Horta Jung, M. - Pfanz, H. - Robin, C. - SiPos, G. - Solla, A. - CeCh,T. Chambery 1, A.S. - Diamandis, S. - HANSEn, E. - Jung, T. - Orlikowski, L.B. - PARKe, J. PROSPERO, S. - WERRES, S. (2014): Strategies of attack and defence in woody plant-Phytophthora interactions. Forest Pathology. doi: 10.1111/efp.12096

SAntini, A. - Biancalani, F. - Barzanti, G. P. - CAPretti, P. (2006): Pathogenicity of four Phytophthora species on wild cherry and Italian alder seedlings. Journal of Phytopathology 154 (3): 163-167.

SZABÓ, I. - LAKATOS, F. - SIPOS, G. (2013): Occurence of soilborne Phytophthora species in declining broadleaved forests in Hungary. European Journal of Plant Pathology 137 (1):159-168.

ThOMIDIS, T. - SotiRopoulos, T. (2003): Pathogenicity of 11 Phytophthora species on CAB-6P cherry rootstock. New Zealand Journal of Crop and Horticultural Science 31 (4):355-360.

THOMIDIS, T. - KARAYIANNIS, I. - TSIPOURIDIS, C. (2008): Susceptibility of thirty cherry genotypes on Phytophthora cactorum, P. citrophthora, P. citricola and P. parasitica. Journal of Phytopathology 156 (7-8): 446-451.

Vettraino, A.M. - Flamini, L. - PizZichini, L. - Prodi, A. - Nipoti, P. - VAnNini, A. - LAgnese, R. (2008): First report of root and collar rot by Phytophthora cryptogea on sweet cherry in Italy. Plant Disease 92 (1): 177. 